\title{
Visualisasi dan Transformasi Kebertubuhan Dalam Film Animasi Planes (Ke Arah Pembentukan Mitos Baru)
}

\author{
Acep Iwan Saidi \\ Ilmu Desain dan Budaya Visual-Fakultas Seni Rupa dan Desain ITB \\ Agung Eko Budiwaspada \\ Desain Komunikasi Visual-Fakultas Seni Rupa dan Desain ITB
}

\begin{abstract}
This research is entitled "Visualization and Transformation of Embodiment in the Film of Planes Animation". As an animation film, Planes is interesting because it is using inanimate objects, in this case the planes, as characters. This fact indicates that the character transformation is done by an animator, from the character of inanimate objects in to live character. By using the methods of structural and semiotic analysis, found that the transformation is done not only for personification (it is made as if the inanimate objects becomes alive). In the Planes, "the living things" not only exist in the mind as imagination, but it is exist out of the mind, as an autonomous reality. Based on that, Planes is the animation film which opens space for creating a new myth in the history of culture. Like the fable as a myth in the tradition of primary orality, Planes allows the formation of myth in digital oral tradition.
\end{abstract}

Key Words: Transformation, visualization, embodiment, personification, metaphor, tradition, myth

\begin{abstract}
ABSTRAK
Penelitian ini bertajuk "Visualisasi dan Transformasi Kebertubuhan dalam Film Animasi Planes".Sebagai film animasi, Planes menarik karena menggunakan benda-benda mati, dalam hal ini pesawat, sebagai tokoh cerita. Fakta ini mengindikasikan dilakukannya transformasi karakter oleh animator, yakni dari karakter "yang mati" ke "yang hidup". Dengan menggunakan metode analisis structural dan semiotik, ditemukan bahwa transformasi tersebut dilakukan melampaui sarana retorika personifikasi (membuatseolaholah yang mati menjadi hidup).Di dalam Planes, "yang hidup" itu tidak berada di dalam pikiran dan imajinasi apresiator sebagai yang seolah-olah, melainkan hadir di luar pikiran, berdiri sendiri sebagai realita sotonom. Berdasarkan hal itu, Planes merupakan film animasi yang membuka ruang bagi terciptanya mitos baru dalam sejarah cerita. Jika fable merupakan mitos dalam tradisi kelisanan primer, Planes memungkinkan terbentuknya mitos dalam tradisi lisan digital.
\end{abstract}

Kata kunci: transformasi, visualisasi, kebertubuhan, personifikasi, metafora, tradisi, mitos. 


\section{PENDAHULUAN}

Animasi, dalam bahasa Inggris, animation, juga termasuk kata yang berhubungan dengannya, animated dan animator, berasal dari bahasa Latin, animate, yang artinya 'bernyawa'. Paul Wells (1998: 10) memberi arti 'to animate' sebagai to give life to, 'memberi ke-(hidup)-an kepada'. Objek yang diberi "nyawa" tersebut termasuk di dalamnya benda mati. Prakoso (2010 :23) mengidentikkan arti "menghidupkan" dengan memberi gerak dan juga kesan bergerak. Hal ini untuk meperluas cakupan bahwa animasi bukan hanya karya dengan objek yang bergerak (film) tetapi juga gambar diam (still picture) yang memberi kesan bergerak, antara lain seni lukis. Mekanisme kerja animasi yang memberikan "nyawa" kepada sesuatu ini, seperti dikatakan Wells, umumnya dilakukan dengan cara memungsikan potensi garis (line) dan bentuk (shape).

Dari sisi mekanisme kerja demikian, animasi merupakan transformasi bentuk, pemindahan realitas ke semacam sketsa yang bergerak atau, untuk genre karya tidak bergerak, animasi identik dengan menghadirkan kesan bergerak. Jika objek yang ditransformasi dari realitas tersebut sosok manusia, misalnya, di dalam animasi sosok itu mengalami rekayasa bentuk, menjadi semacam sketsa manusia. Sudah tentu, di dalam proses demikian terjadi pengurangan, penambahan, pelucuan, pengabnormalan, dan lain-lain. Namun, sampai batas terjauh transformasi, animasi tidak mengubah sisi dalam (deep structure) atau ruh, termasuk sifat dan karakter objek. Dengan kata lain, sifat-sifat kemanusiaannya tetap melekat.

Film animasi, sejauh ini, di samping mentransformasi sosok manusia, umumnya mengambil tokoh binatang sebagai "bahan dasar" transformasi bentuk sekaligus ceritanya. Pada genre ini, proses pentransformasian bisa dikatakan lebih kompleks. Sebelum mentransformasi menjadi animasi, seorang animator tentu harus menstranformasi sifat dan karakter binatang menjadi sifat dan karakter manusia. Hal ini harus dilakukan sebab di dalam film, binatang tersebut harus berperan sebagai tokoh cerita. Beberapa film animasi binatang seperti Shaun The Sheep memang tidak mempersonifikasinya secara utuh. Pada Shaun The Sheep, binatang domba sebagai tokohnya tetap tidak bisa berbicara seperti manusia, tetapi secara keseluruhan perilakunya mirip dengan perilaku manusia.

Pengkarakteran binatang menjadi manusia mungkin juga tidak terlalu rumit mengingat dalam khasanah kebudayaan semua bangsa di dunia ini, binatangbinatang tertentu telah memiliki karakter tersendiri, bahkan telah menjadi mitos. Karakter mitologis binatang memang bisa berbeda-beda di setiap bangsa seturut kebudayaan bangsa tersebut, tetapi beberapa bintang ada yang telah memiliki karakter dan peran universal, seperti singa sebagai raja hutan dan kancil sebagai binatang cerdik. Film animasi dengan tokoh binatang faktanya memang sering mengambil karakter yang telah terbentuk di dalam cerita binatang (fabel) sedemikian. Film animasi The Lion King (1994) adalah salah satu contohnya.

Hal yang menarik dari perkembangan film animasi adalah penggunaan objekobjek mati (bukan makhluk hidup) sebagai tokoh ceritanya. Objek-objek tersebut, antara lain, berupa alat transportasi seperti kereta api (trains), kendaraan roda empat (cars), dan pesawat terbang (planes). Dibandingkan dengan film animasi yang menggunakan karakter tokoh manusia dan binatang, film animasi dengan karakter 
benda mati lebih kompleks dan unik. Dikatakan kompleks karena animator dituntut lebih kreatif dalam melakukan transformasi mengingat objek-objek tersebut tidak bernyawa, tidak seperti halnya manusia atau binatang. Bagaimanapun, memberi "nyawa" sekaligus karakter manusia kepada benda-benda tersebut bukanlah persoalan mudah.

Kompleksitas itu sekaligus menunjukkan keunikan sebab kereta api yang bisa berbicara, misalnya, bukan sesuatu yang lumrah. Kita masih bisa memahami jika sebuah film berkisah dengan tokoh binatang yang bisa berbicara, sebab setidaknya, seperti telah disinggung di atas, dalam kebudayaan hal itu dapat ditelusuri jejaknya ke dalam sejarah, yakni ke dalam fabel. Akan tetapi, benda mati seperti kendaraan yang bisa berbicara tidaklah demikian. Fenomena inilah yang menyebabkan penulis tertarik untuk melakukan penelitian terhadapnya. Dalam hal ini penulis memilih film animasi Planes sebagai objek risetalasan pemilihannya dijelaskan di bagian lain.

Terkait dengan topik tersebut beberapa persoalan dapat dirumuskan sebagai berikut. Pertama, bagaimana animator film animasi dengan objek mati, dalam hal ini pesawat terbang melakukan transformasi kebertubuhan sehingga objek mati tersebut menjadi hidup? Kedua, bagaimana struktur dan relasi cerita yang dikonstruksinya? Ketiga, bagaimana pesan dan makna komunikasi yang dikirim untuk penerima atau apresiatornya?

Berdasarkan tiga rumusan tersebut penelitian ini dengan sendirinya mengindikasikan tercapainya tiga tujuan sebagai konsekuensi dari tiga permasalahan tadi. Tiga tujuan yang dimaksud adalah 1) memahami mekanisme transformasi yang dilakukan animator dalam menciptakan karya film animasi yang menggunakan karakter objek mati, dalam hal ini pesawat terbang dalam film animasi Planes, 2) memahami struktur dan relasi cerita yang dibangunnya, dan 3) memahami makna dan pesan komunikasi yang dikirim kepada apresiatornya.

Tentu dibutuhkan alat dan cara yang tepat untuk mencapai tiga tujuan tersebut. Dalam kajian penulis, tiga tujuan itu baru dapat dicapai setidaknya dengan menggunakan dua metode, yakni struktural dan semiotik. Diketahui bahwa kedua metode ini berada dalam satu rumpun, yakni bahasa, meskipun semiotika memiliki versi lain karena salah satu pelopornya, Charles Sanders Peirce (1839-1914), berasal dari ranah kelimuan yang berbeda. Peirce menyusun teorinya berdasakan ranah filsafat sains, khususnya logika (Short, 2007: 1-2).

Berangkat dari ranah tersebut, Peirce menempatkan tanda dalam relasi segi tiga trikotomi (ke-tigaan) sebagai berikut.

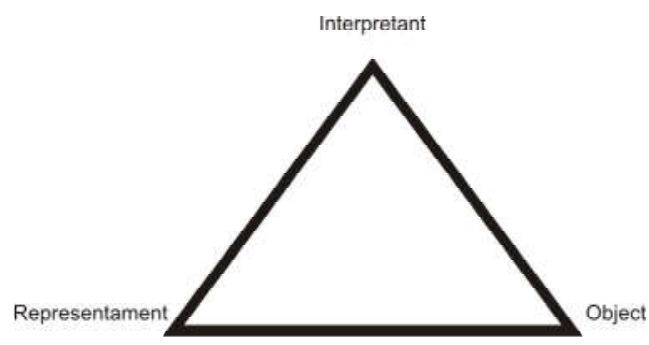

Gambar.1:

Bagan Trikotomi Peirce

Representament adalah sesuatu yang bersifat konkret yang mewakili sesuatu yang lain, object adalah realitas yang direpresantasikan, dan interpretant adalah makna yang hadir di benak interpretator (apresiator). Konsep dasar ketigaan tersebut kemudian melahirkan taksonomi tanda ketigaan juga. Bagaimana sesuatu mewakili sesuatu yang lain melahirkan taksonomi tanda sinsignqualisign-legisign; bagaiamana objek 
direpresentasikan melahirkan taksonomi icon-index-symbol; dan bagaimana makna hadir di benak apresiator memun-culkan rheme-dicisign-argument (Short, 2007: 207234). Penelitian ini sendiri lebih terfokus pada identifikasi objek. Dengan demikian, pembahasannya lebih banyak menyangkut pada hubungan kemiripan (icon), hubungan 'yang menunjukkan' (index), dan kesepakatan (symbol).

Sementara itu, semiotika yang dikatakan satu rumpun dengan metode struktural bersumber dari ranah dan pelopor yang sama, yakni ahli linguistik struktural Ferdinand de Saussure (1857-1913). Namun, dalam keserumpunan ini juga tetap terdapat perbedaan mendasar sebab Saussure sendiri memang tidak mengembangkan semiotika secara khsusus. Berangkat dari teorinya bahwa bahasa merupakan tanda yang paling sempurna, Saussure memprediksi akan lahirnya satu ilmu tentang tanda yang ia sebut semiologi. Saussure sendiri tidak mengembangkan ilmu ini. Saussure menulis:

"It is therefore possible to conceive of a science which the role of sign as part of social life. It would form part of social psychology, and hence of general psychology. We call it semiology (from the Greek semeion, 'sign). It would investigate the nature of sign and the laws governing them"

(Saussure, 19901: 5).

Semiotika atau lebih tepat semiologi yang diramalkan Saussure di atas selanjutnya dikembangkan Roland Barthes dengan beberapa perbedaan. Berbeda dengan Saussure, Barthes menempatkan struktur bahasa tidak sebatas "di dalam bahasa" itu sendiri, melainkan mendudukkannya dalam konteks yang lebih luas, yakni kebudayaan. Barthes mengedepankan dua tingkatan pesan dan makna bahasa, yakni denotasi (pertama) dan konotasi (kedua).
Konotasi lantas dapat berkembang menjadi mitos. Mitos, kata Barthes, adalah model artikulasi, myth is a type of speech (Barthes, 1983: 109). Di sini bisa dikatakan bahwa mitos adalah tahap puncak dari operasi bahasa.

Di dalam penelitian ini, semiotika yang digunakan berasal dari dua versi di atas sekaligus. Semiotika Peirce penulis pakai untuk membongkar permasalahan pertama, yakni tentang transformasi kebertubuhan dalam animasi, yang dilakukan melalui mekanisme personifikasi dan metaforarisasi. Bagi penulis, konsep trikotomi (ke-tigaan) tanda Peirce lebih mudah digunakan untuk membongkar tanda-tanda dalam film animasi daripada dikotomi (ke-duaan) Saussure atau konsep tanda Barthes. Sejauh mana, misalnya, dalam personifikasi, bagian tertentu pada elemen pesawat (sebagai tanda) memiliki kemiripan (ikonik) dengan elemen yang terdapat pada anatomi tubuh manusia, atau lebih jauh elemen tersebut berposisi sebagai indeks dan simbol. Taksonomi tanda ke-tigaan ikon-indekssimbol dari Peirce ini lebih spesifik dan mudah diaplikasikan daripada menggunakan konsep ke-duaan penanda-petanda Saussure atau denotasi-konotasi Barthes.

Selanjutnya, untuk menjawab permasalahan kedua, penulis memakai metode struktural. Di sini, yang akan dianalisis adalah relasi-relasi dalam cerita. Dengan kata lain, analisis akan terfokus pada konstruksi atau struktur narasi. Dari sini diharapkan bisa dibongkar sistem tertentu sebagai basis konseptual animator dalam berkarya. Sebatas mana, misalnya, film animasi jenis ini meninggalkan konstruksi narasi konvensional atau justru sebaliknya tidak beranjak dari konvensi tersebut. Strukturalisme sendiri, sebagai basis metode struktural, mempersepsi realitas sebagai bangunan struktur. Di dalam kajian ini, yang 
dipentingkan adalah relasi dan struktur itu sendiri ketimbang sesuatu yang berada di luar dirinya. Strukturalisme, seperti disimpulkan Hoed (2011: 58), bekerja dalam tiga prinsip dasar, yakni 1) struktur dan sistem selalu hadir bersama, 2) struktur bersifat abstrak, sesuatu yang hadir dalam kognisi manusia, dan 3) struktur dan sistem merupakan satuan tertutup dan memenuhi dirinya sendiri.

Pengkarakteran lewat personifikasi dan pemetaforan yang dilanjutkan pada tahap penyusunan narasi tentu dimotivasi oleh tujuan-tujuan komunikasi. Pada level ini, sebagaimana dirumuskan pada permasalahan ketiga di atas, sejatinya diketahui makna dan pesan komunikasi yang terkandung di dalam film. Untuk membongkar hal ini, penulis kembali menggunakan semiotika. Akan tetapi, pada bagian ini yang digunakan adalah semiotika Barthes yang berbasis pada strukturalisme Saussure dengan beberapa perbedaan sebagaimana telah disinggung di atas.

Pemakaian kembali semiotika - meskipun dari aliran yang berbeda-dalam menjawab rumusan permasalah ketiga tersebut dengan sendirinya menunjukkan bahwa teori dan metode utama yang digunakan dalam kajian ini adalah semiotika. Untuk itu perlu dikemukakan alasan mengapa metode ini menjadi pilihan. Sebagaimana dikatakan Chandler dalam Khajavi (2011: 46), kita tidak memiliki cara untuk memahami apa pun kecuali melalui tanda-tanda dan kode yang terorganisir". Dan "semiotika merupakan cara untuk mengungkap proses pembuatan makna dan untuk menjawab pertanyaan tentang bagaimana realitas diwakili". Khajavi yang menganalisis film animasi dokumenter sampai pada kesimpulan bahwa "pembuatan film dokumenter dapat diasumsikan sebagai praktek pengorganisasian kode, dan karena itu, film dokumenter dapat dipahami sebagai suatu sistem kode terorganisir atau sistem tanda". Sepaham dengan pandangan ini, penulis berpendapat bahwa hal yang sama dapat diterapkan pada film animasi elektronik yang dikaji di dalam artikel ini.

Namun demikian, harus disampaikan bahwa uraian mengenai metode tersebut tidak dibarengi dengan kajian mendalam terhadap teori yang mendasarinya. Hal ini karena faktor ruang yang penulis anggap tidak memungkinkan. Bagaimanapun uraian tentang teori-teori itu memerlukan medan yang lebih memadai, bukan pada sebuah tulisan pendek seperti ini. Oleh sebab itu, di sini hanya ditinjau aspek yang diangap penting sebagaimana telah dikemukakan secara singkat tadi. Selanjutnya, hal tersebut diturunkan secara aplikatif ke hal-hal yang berkaitan dengan tahap dan strategi penelitian sebagaimana penulis jelaskan berikut ini.

Pertama, mengidentifikasi, mengklasifikasi, dan menganalisis berbagai tanda pada objek penelitian berdasarkan perspektif semiotika Peirce. Di sini, analisis terfokus pada pembentukan karakter animasi atau penokohan. Karena pada mulanya tokoh merupakan makhluk tidak hidup, titik menarik analisis terletak pada bagaimana upaya animator mengubah makhluk tidak hidup tadi menjadi hidup. Hal-hal apa saja, misalnya, yang mampu menjadi penanda pengubah makhluk tidak hidup menjadi hidup. Dengan kata lain, analisis akan terpusat pada mekanisme personifikasi dan metaforarisasi yang dilakukan animator.

Kedua, mengidentifikasi dan menganalisis aspek narasi, baik narasi verbal maupun visual dalam perspektif strukturalisme Saussure. Bagaimana, 
misalnya, makhluk tidak hidup yang telah diberi "ruh" ditempatkan di dalam struktur cerita, bagaimana tokoh-tokoh animasi tersebut saling berelasi. Untuk hal ini, perspektif dikotomi tentang relasi dalam strukturalisme Saussure digunakan sebagai landasan kajian.

Ketiga, mengidentifikasi dan menganalisis pesan dan makna yang dikonstruksi oleh dua tahap analisis di atas. Metaforarisasi pada analisis di tahap pertama dengan sendirinya juga berbicara mengenai konotasi yang dengan begitu dimungkinkan menyentuh pesan dan makna di baliknya. Akan tetapi, dalam analisis tersebut pesan dan maknanya merupakan pesan dan makna tubuh tokoh secara parsial atau yang berdiri sendiri sebagai tokoh. Sedangkan yang dimaksud pesan dan makna pada tahap ini merupakan yang berkelindan di dalam urutan peristiwa, ruang, waktu, dan jalinan antartokoh itu sendiri. Dengan kata lain, yang dimaksud adalah pesan dan makna dalam narasi, terutama pesan dan makna konotatif yang ditimbulkan oleh jalinan narasi tadi.

Di dalam praktiknya, tiga poin analisis di atas tidak ditempatkan sebagai tahapan secara linear (mulai dari yang pertama dan berakhir pada yang ketiga). Dalam beberapa aspek, operasi ketiganya dilakukan secara bersamaan. Hal yang terpenting adalah bahwa pada akhirnya analisis tiga hal tersebut ditujukan pada satu sasaran, yakni untuk terumuskannya sebuah ciri khas atau karakteristik yang dibangun oleh keseluruhan aspek karya yang diteliti sebagai genre film animasi.

\section{Data dan Analisis}

Objek penelitian ini adalah film animasi berjudul Planes. Film ini diproduksi Disney Toon Studios dan dirilis oleh Walt Disney Pic- tures pada 2013. Film yang disutradarai Klay Hall dan dipro-duseri Traci Balthazor ini berdurasi 92 menit. Di Indonesia, Planes juga telah diadaptasi ke dalam buku (The Movie Storybook) oleh Lisa Marsoli (Gramedia, 2013).

Film animasi yang menggunakan benda mati atau makhluk tidak hidup sebenarnya bukan hanya Planes. Sebelumnya Disney Toon Studios merilis film animasi sejenis berjudul Cars. Sesuai judulnya, jika Planes bertokoh pesawat, Cars bertokoh kendaraan roda empat, yakni mobil balap. Selain itu, terdapat juga film animasi sejenis, tetapi diperuntukkan khusus bagi anak-anak (lebih tepat disebut film animasi boneka), yakni Thomas and Friends; film boneka animasi yang menggunakan kereta api sebagai tokohnya.

Planes dipilih sebagai objek riset sebab menurut penulis Planes lebih kompleks daripada Cars maupun Thomas. Dibandingkan dengan Cars, kedua film animasi ini memang berkisah mengenai balapan, tetapi posisi pelakunya berbeda. Pada Cars, Mc.Queen sebagai tokoh utama adalah pembalap sehingga kisahnya yang juga tentang balap mobil linear dengan ketokohannya. Sedangkan dalam Planes terjadi ketidakseimbangan relasi. Dusty, tokoh utamanya, hanyalah penyemprot ladang, pesawat kecil yang tidak dirancang untuk balap. Pada sisi ini, Planes lebih kompleks dan menarik. Kompleksitas inilah yang menyebabkan penulis memilihnya sebagai objek riset. Sementara itu, Planes tidak bisa dibandingkan dengan Thomas sebab genrenya memang berbeda. Thomas merupakan film boneka yang diperuntukkan bagi anakanak.

\section{Pokok Cerita Planes}

Planes berkisah tentang sebuah pesawat kecil bernama Dusty yang mengikuti reli keliling dunia bersama pesawat reli 
terkenal seperti Ripslinger, Bulldog, Ishany, Ned, dan Zed. Seorang mekanik (berwujud mobil) bernama Dottie mengatakan bahwa Dusty hanyalah pesawat penyemprot ladang, tidak diperuntukkan bagi balapan. Namun, Dusty tetap bersikeras berlatih dan mengikuti babak kualifikasi. Di babak kualifikasi, Dusty sebenarnya gagal. Ia hanya mampu menduduki peringkat keenam, sementara syarat untuk mengikuti reli keliling dunia harus masuk ke dalam lima besar. Untungnya, peserta kelima ternyata didiskualifikasi sehingga sebagai peringkat enam Dusty berhak menggantikannya.

Dalam pelaksanaan reli tersebut, Dusty mengalami banyak rintangan. Pertama, karena takut ketinggian, Dusty selalu terbang rendah. Akibatnya, ketika pada putaran pertama reli dimulai dari New York ke Islandia melintasi lautan Atlantik Utara, Dusty kedinginan karena terbang di dekat permukaan laut. Ia kedinginan karena terjadi badai salju. Ia juga harus bekerja keras menghindari gunung-gunung es. Akhirnya Dusty hanya bisa tiba di Islandia berjam-jam setelah yang lain mendarat. Kedua, karena terbang rendah itu pula, ketika di rute Jerman-Nepal, Dusty tidak bisa melintasi pegunungan Himalaya. Ia terpaksa melintasi terowongan kereta api. Meskipun tiba ke Nepal yang pertama, Dusty nyaris mengalami kecelakaan, yakni hampir bertabrakan dengan kereta yang akan memasuki terowongan dari arah berlawanan.

Namun, karena kegigihannya, Dusty dapat menyelesaikan seluruh balapan dan keluar sebagai pemenang. Di samping gigih, Dusty juga baik hati. Ia, misalnya, pernah menolong Bulldog yang mengalami kecelakaan ketika dalam penerbangan menuju Jerman. Oleh sebab itu, Dusty juga disenangi peserta reli, kecuali Ripslinger, sang juara bertahan yang sejak awal sudah bersikap sombong. Dusty, dengan demikian, tidak hanya keluar sebagai juara lomba, tetapi juga sebagai pahlawan.

Pertanyaannya, sebagaimana telah dirumuskan, bagaimanakah pesawatpesawat yang notabene sebagai makhluk tidak hidup tersebut berinteraksi dan bahkan berkompetisi? Riset ini menemukan beberapa hal menarik tentang bagaimana karakterisasi yang dilakukan animator, yang dalam perspektif semiotika dapat dikatakan sebagai cara penandaan dan pembentukan kode (encoding). Proses ini dilakukan baik secara verbal maupun, terutama, secara visual. Bagian-bagian selanjutnya dari tulisan ini berisi pembahasan hal tersebut.

\section{Sistem Penamaan Sebagai Pemetaforan}

Hal pertama yang menarik dikaji adalah mekanisme pemberian nama. Planes sendiri, sebagai judul film animasi ini, dengan jelas menunjuk ke arti denotatif, yakni pesawat (jamak). Dalam semiotika Peirce, planes dapat dikategorikan sebagai indeks, tanda yang menunjuk pada sesuatu, yakni menunjuk ke pesawat-pesawat atau dunia pesawat. Ini adalah penanda bahasa verbal (verbal index); saat kata ini diucapkan atau, terutama, ditulis, pendengar atau pembaca segera akan dituntun ke sebuah objek, yakni pesawat atau hal yang berkaitan dengan dunia pesawat.

Dari taksonominya, ketika kata planes dibaca, gambaran pertama yang muncul tentu saja pesawat-peswat. Tapi, hal ini menjadi menarik jika kata planes tersebut ditulis sebagai judul sebuah cerita pada jilid depan buku atau poster film yang di bawah kata itu juga terdapat gambar pesawat. Kata dan gambar tersebut jelas menjadi indeks. Hanya, kita harus berpikir dua kali ketika buku tadi dibaca atau filmnya ditonton. Di 
situ ternyata ditemukan bahwa yang dimaksud Planes bukan semata tentang pesawat atau dunia pesawat (pemahaman yang lumrah), tetapi ternyata cerita dengan pesawat sebagai tokohnya, pesawat yang hidup seperti halnya manusia (sesuatu yang tidak lumrah). Dengan demikian, dalam perspektif taksonomi tanda Peirce (Short, 2007: 208-214), Planes sebagai judul buku atau poster film adalah sinsign, sebuah tanda sementara yang maknanya belum definitif. Planes menjadi tanda legisign (bermakna definitif) ketika buku telah dibaca atau film telah ditonton.

Selanjutnya, di dalam film, pesawatpesawat tersebut diberi nama, antara lain Dusty, Ripslinger, Skipper, Buldog, Ishani, dan lain-lain. Pemberian nama ini merupakan pemetaforan awal yang diposisikan sebagai mekanisme transformasi dari karakter benda-benda (tidak hidup) menjadi manusia (hidup). Pemetaforan ini melampaui personifikasi, sebuah pemiguraan yang hanya membuat sesuatu menjadi seolah-olah hidup seperti manusia, misalnya pada ungkapan "daun kelapa yang melambai-lambai".

Melewati posisi seolah-olah tersebut, di dalam film animasi Planes, pesawatpesawat menjadi betul-betul hidup (bernyawa) sebagaimana layaknya manusia. Dengan kata lain, pemberian nama itu identik dengan pemberian "nyawa atau ruh" yang menjadikan benda-benda mati (pesawat) menjadi hidup. Pesawat-pesawat yang telah menjadi manusia ini lantas berinteraksi pada sebuah ruang yang lebih dulu dibingkai oleh judul Planes dalam posisinya sebagai indeks yang menunjuk ke dunia tempat pesawat-pesawat yang telah memiliki karakter manusia sebagaimana diuraikan tadi.

Dalam interaksi sedemikian tentu dibutuhkan karakterisasi masing-masing tokohnya. Bagaimanapun, dialog atau interaksi dari beberapa tokoh baru-akan berlangsung dengan baik jika masingmasing tokoh memiliki karakter yang berbeda. Sebuah cerita selalu meniscayakan hal ini. Oleh sebab itu, di dalam cerita selalu dikenal tokoh protagonis, antagonis, figuran, dan lain-lain.

Protagonis dalam film animasi Planes bernama Dusty. Nama ini tampak bukan asal dilekatkan sebagai panggilan belaka, melainkan merupakan hasil seleksi dan pertimbangan tertentu. Dusty, dalam bahasa Indonesia berarti "berdebu". Dari sini bisa dikatakan bahwa melampaui sekedar panggilan, Dusty adalah indeks. Ia penanda yang menunjuk pada identitas. Dusty adalah karakter. Sebagai pesawat kecil penyemprot hama di ladang, Dusty hanyalah sosok yang secara fisik tidak menarik. Ia pendek, cenderung bulat, dan kotor (berdebu).

Di ladang, Dusty berteman dengan Chug, sebuah truk bahan bakar. Chug seorang yang periang, tapi juga meletupletup. Dengan bersemangat dan bergembira ia melatih Dusty terbang sebagai pereli. Karakter Chug sedemikian identik dengan namanya, chug (Inggris), 'letusan kecil", seperti letupan yang keluar dari knalpot mobil tua. Dan itulah suara Chug, si pengangkut bahan bakar.

Nama lain yang menarik ditilik adalah Skipper. Ia adalah pelatih Dusty. Meskipun sudah tua dan rapuh, Skipper sangat berwibawa. Di dalam bahasa Indonesia, Skipper berarti komandan atau majikan. Sosok fisik dan karakter Skipper memang memadai menjadi seorang komandan. Tubuhnya panjang (tinggi), besar, berwarna gelap, dan menyeramkan. Skipper juga mantan prajurit perang yang galak. Ketika Dusty datang untuk memintanya menjadi pelatih untuk pertama kalinya, Skipper 
menghardik Dusty sambil membanting pintu.

Satu nama lagi yang perlu disebut adalah Bulldog. Sebagaimana diketahui, Bulldog adalah sejenis anjing dengan kepala besar dan rahang kuat yang meonjol ke bawah, termasuk ke dalam jenis anjing pemburu. Karakter ini juga melekat pada tokoh pesawat Bulldog tadi. "Setiap pesawat harus berjuang sendiri!", katanya dengan kasar kepada Dusty.

Demikian, beberapa nama yang dipilih di atas tampak merupakan nama yang tidak tanpa asosiasi, tidak tanpa pesan. Namanama tersebut adalah nama-nama semiotis, penanda yang merujuk pada konsep tertentu. Hal ini berarti bahwa penamaan pada film animasi Planes bersifat sistemik. Menurut penulis, penamaan demikian merupakan bagian dari mekanisme transformasi kebertubuhan, dari "yang mati" ke "yang hidup" dalam film bersangkutan.

\section{Visualisasi Tubuh dalam Transformasi Karakter}

Dalam filsafat Yunani klasik dikatakan manusia adalah hewan yang berbicara. Dengan kata lain, kemampuan berbicara adalah identitas manusia yang membedakannya dari hewan. Tentu pandangan ini bisa diperdebatkan sebab dari segi fisik manusia juga berbeda dengan hewan. Terlepas dari teori evolusi Darwin, faktanya hari ini manusia berpenampilan berbeda dari kera yang hingga hari ini kera juga masih tetap berpenampilan sebagai kera. Jika manusia berasal dari kera-berubah secara evolutif - seharusnya hari ini sudah tidak ada lagi kera. Di sisi lain, jika hari ini ditemukan hewan yang berbicara layaknya manusia, ia akan disebut keajaiban jika tidak mau disebut keganjilan, sesuatu yang tidak lumrah atau menyalahi kodrat.
Namun demikian, dalam konteks penciptaan film animasi, filsafat tersebut memudahkan atau setidaknya memberi ruang kreativitas kepada para animator dalam menciptakan karya dengan tokoh binatang yang bisa berbicara. Sebagaimana diketahui, banyak film animator dengan mengambil binatang sebagai tokohnya. Hal ini juga dipermudah oleh sejarah tradisi lisan primer (Ong, 2004). Dalam tradisi lisan dikenal fabel, yakni cerita rakyat dengan binatang sebagai tokohnya. Filsafat Yunani klasik dan fenonema fabel ini tentu dapat menuntun apresiator dalam memahami apa yang ditampilkan film animasi yang mengambil tokoh binatang berbicara. Penulis sendiri menyebut animasi jenis ini sebagai fabel elektronik.

Berbeda halnya dengan film animasi yang menggunakan tokoh makhluk tidak hidup (benda mati) sebagaimana dalam Planes. Dalam animasi jenis ini dibutuhkan imajinasi dan kreativitas tertentu yang mampu menstrarformasi tubuh makhluk tidak hidup menjadi makhluk hidup. Dalam kasus Planes, animator harus berusaha mentransformasi "tubuh pesawat" menjadi tubuh manusia. Harus dilakukan alih kode kepesawatan ke kode ke-manusiaan. Dalam perspektif semiotika Peirce, salah satu cara yang bisa dilakukan adalah dengan ikonisasi, yakni membuat copy, atau menciptakan ikon manusia.

Dalam Planes, transformasi wujud visual (fisikal) tersebut dilakukan dengan beberapa hal. Pertama, tokoh-tokoh pesawat tidak berubah wujud secara total menjadi tokoh manusia. Secara umum, imej pesawat tetap dipertahankan. Artinya, tidak terjadi ikonisasi atau pengubahan bentuk menjadi mirip manusia (copy) secara keseluruhan. Perhatikan sosok Dusty berikut ini: 


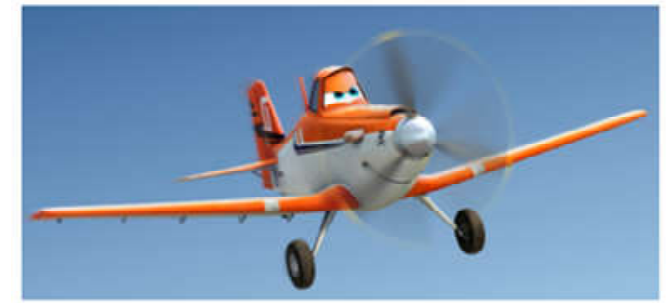

Gambar.2:

foto modifikasi penulis; sumber Planes

Tampak bahwa Dusty adalah pesawat kecil dengan desain yang tidak proporsional: pendek, sayap depannya terlalu panjang sedangkan sayap belakang dan ekor terlalu kecil. Sementara itu, di bagian tengah terdapat tonjolan ke atas seperti sebuah topi. Ini memang tipe pesawat untuk penyemprot ladang. Dusty bisa-jadi imej pesawat yang mengambil Cessna sebagai modelnya. Tapi, tubuh Cessna tampak lebih proporsional. Perhatikan pesawat Cessna di bawah ini:

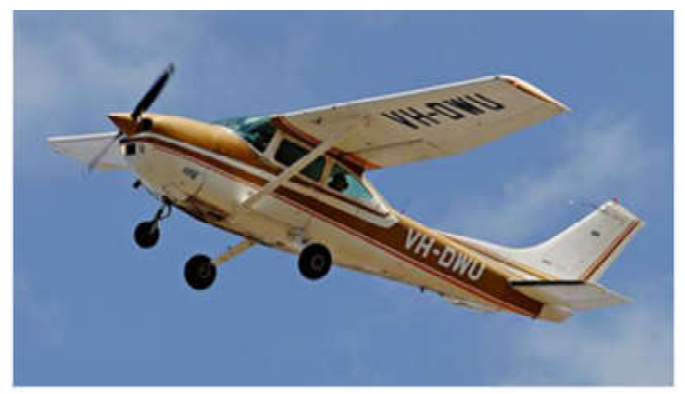

Gambar. 3

Sumber: www. Tempo.co/news/ 2013. Diunduh 30 April 2015

Diketahui bahwa animasi memang selalu melakukan deviasi atas objek (subjek) yang menjadi basisnya. Deviasi dilakukan justru untuk menunjukkan bahwa objek telah direpresentasikan dalam dunia animasi (realitas animasi) itu sendiri. Dalam Planes, deviasi tersebut dilakukan dengan tujuan lain-selain tujuan menjadikannya sebagai animasi tadiyakni sebagai analog dari anatomi tubuh manusia. Untuk hal ini, di bagian tengah dibuat topi yang lebih menonjol ke atas. Beranalogi pada tubuh manusia, bagian ini adalah kepala dan sekaligus muka (wajah). Asosiasi demikian menjadi semakin kuat sebab di bagian ini terdapat dua bulatan kecil, yang tidak lain merupakan ikon dari mata. Perhatikan bagian tersebut yang dibesarkan (zoom) berikut ini:

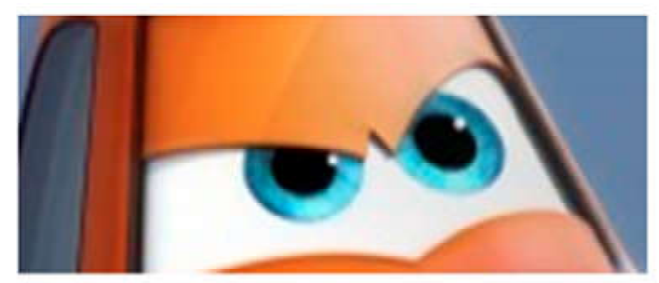

Gambar.4:

foto modifikasi penulis, sumber Planes

Bagian wajah rupanya bukan hanya itu. Moncong pesawat menjadi bagian lain dari wajah, yakni sebagai hidung. Di bagian bawah hidung dibuat lubang kecil berbentuk opal yang tidak lain adalah mulut. Bagian inilah (mulut) yang tampak paling aktif bergerak mengikuti suara para pengisi suara (dubber).

Sampai di situ tampak bahwa Dusty sudah dapat diimajinasikan sebagai tubuh manusia. Strukturnya adalah topi sebagai kepala dan wajah, bagian yang memanjang sebagai badan (kecuali bagian depan yang berfungsi sebagai hidung), sayap sebagai tangan, dan roda sebagai kaki. Jika ditarik secara vertikal, imej Dusty bisa menjadi seperti di bawah ini:

Namun, sejauh itu tampak bahwa secara keseluruhan postur tubuh tersebut tidak ikonik. Anatomi tubuh Dusty tidak mirip (copy) dengan tubuh manusia. Bagian tudung, lampu, moncong, dan lubang di bagian bawah moncong secara sendirisendiri memang dibuat ikonik, yakni 


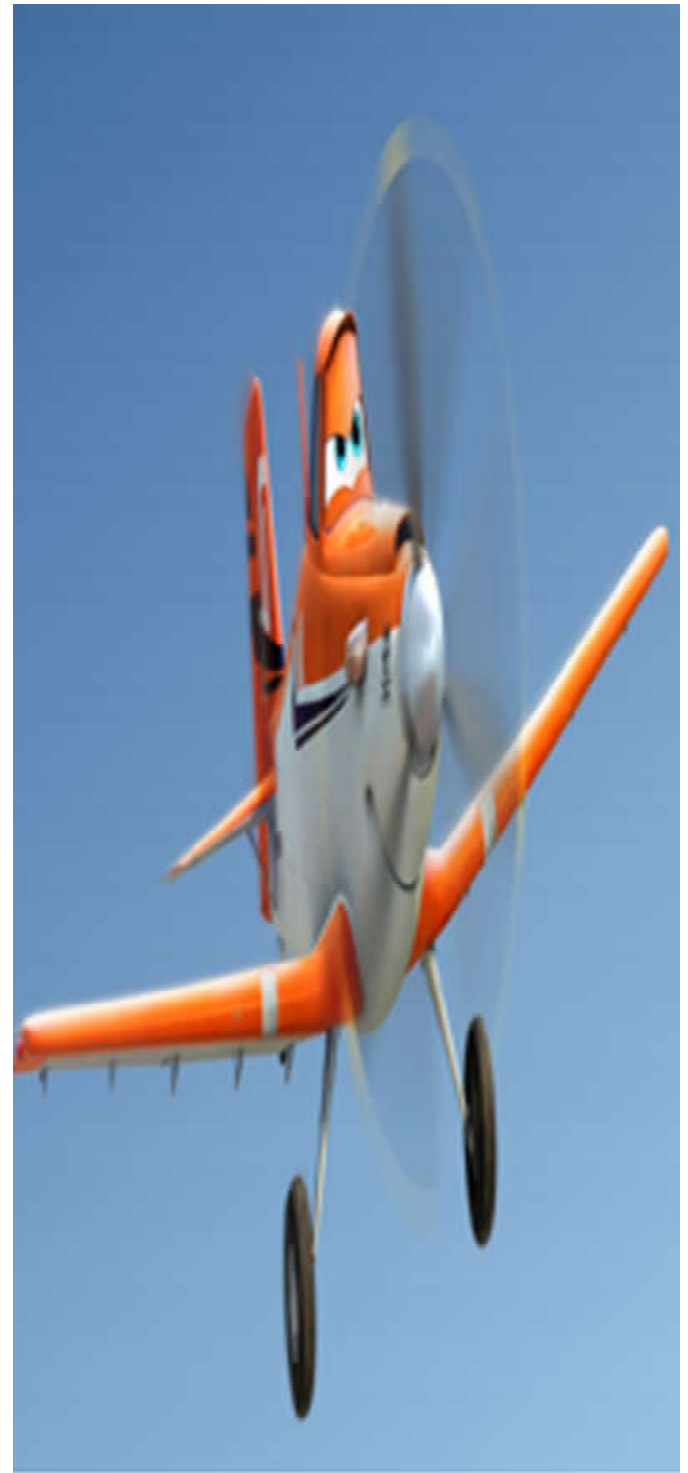

Gambar.5

Foto modifikasi penulis, sumber: Planes

tudung menjadi mirip kepala, lampu mirip mata, moncong mirip hidung, dan lubang di bawah moncong menjadi mirip mulut. Rangkaian bagian-bagian ini dengan sendirinya "memaksa" imajinasi apresiator untuk menempatkan sayap depan sebagai tangan, dan roda sebagai kaki. Akan tetapi, sayap dan roda tidak dibuat ikonik, keduanya lebih tepat disebut sebagai indeks. Dengan demikian, secara keseluruhan anatomi tubuh Dusty menjadi gabungan antara ikon dan indeks. Lebih jelas, bagian-bagian tersebut ditampilkan dalam tabel berikut:

Fakta anatomi tubuh sedemikian menyebabkan Dusty berada dalam dua asosiasi (bisosiasi) secara bersamaan, yakni pesawat sekaligus manusia. Pemaduan asosiasi seperti ini memang lumrah dilakukan dalam animasi. Penonton film animasi umumnya dibawa dalam situasi ini. Film Animasi dengan tokoh binatang menempatkan penonton berada di antara sifat dan wujud binatang dengan sikap dan wujud manusia. Film animasi untuk anakanak, Spongebob, misalnya, bisa disebut sebagai contoh. Nama Spongebob itu sendiri menunjukkan pemaduan kedua hal tersebut. Sponge berarti bunga karang, sedangkan $b o b$ adalah nama panggilan untuk anak laki-laki.

Sebagaimana telah diuraikan, pada Planes, Dusty diberi sifat-sifat manusia dan beberapa bagiannya diikonisasi menjadi mirip tubuh manusia, tetapi sebagian besar tetap dipertahankan sebagai tubuh pesawat. Hal yang sama juga dilakukan pada tokoh-tokoh pesawat lain (Bulldog, Skipper, Ripslinger, dan lain-lain). Hal yang menarik, bagian tubuh yang diikonisasi itu sama untuk semua pesawat, yakni bagian kepala (ditambahkan ikon mata, hidung, dan mulut). Dengan perkataan lain, mekanisme pemetaforannya sama untuk semua pesawat. Hal ini berarti bahwa transformasi dari tubuh makhluk tidak hidup (kepesawatan) ke makhluk hidup (ke-kemanusiaan) telah menjadi model standar dan sistemik. Dalam perspektif strukturalisme Saussure, mekanisme ini terkategori sebagai langua. Susunan tubuh pesawat yang telah diimajinasikan sebagai tubuh manusia sedemikian telah menjadi tata kalimat (sintax) dalam tata bahasa (grammer). Perhatikan pesawat-pesawat lain dalam Planes berikut ini: 
Tabel 1: Elemen Visual, konsep dan tanda

\begin{tabular}{|c|c|c|c|}
\hline ELEMEN VISUAL & DESKRIPSI & KATEGORI TANDA & KONSEP \\
\hline & Tudung & Ikon & kepala \\
\hline & Lampu & Ikon & mata \\
\hline & Moncong & Ikon & hidung \\
\hline & $\begin{array}{l}\text { lubang di bawah } \\
\text { moncong }\end{array}$ & Ikon & mulut \\
\hline & badan pesawat & Index & $\begin{array}{l}\text { badan } \\
\text { manusia }\end{array}$ \\
\hline & Sayap & Index & Tangan \\
\hline & Roda & Index & Kaki \\
\hline
\end{tabular}

Bagian kepala (termasuk di dalamnya wajah) menjadi pilihan karena di dalam tubuh manusia, kepala merupakan identitas. Bagian ini yang menyebabkan satu sama lain saling mengenal. Bagaimanapun kita tidak bisa mendeteksi tubuh tertentu sebagai milik siapa jika ia tidak memiliki kepala dan wajah. Mata, yang pada Dusty dan tokoh-tokoh cerita lain merupakan bagian yang aktif, pada tubuh manusia memang menempati posisi utama. Synot (2003: 370-407) menguraikan dengan panjang lebar indera penglihatan ini. Menurutnya, mata merupakan indera yang

Tabel 2: Bentuk dan gaya visual

\begin{tabular}{llll}
\hline Ripslinger & Bulldog & Ned and Zed & Bravo and Echo \\
\hline & & \\
\hline
\end{tabular}


sangat vital yang taktergantikan. Mata merupakan identitas manusia, bagian penting eksistensi. Syinot menulis:

"Mata adalah simbol diri, bukan hanya di dalam warnanya melainkan juga di dalam ekspresinya...Mata tetap menjadi organ tertinggi dalam komunikasi nonverbal. Tatapan yang jauh, pandangan kemarahan yang panas, tatapan dingin jijik yang dingin, kerlingan cabul, pandangan ke sana kemari, semuanya mengatakan lebih dari kata-kata dan mungkin sungguh-sungguh lebih dapat dipercayai" (2003: 399 \&402).

Berdasarkan hal itu, sekali lagi, bagian kepala dan wajah menjadi fokus pemetaforan. Bagian tubuh ini menjadi simile atau sinekdoke pars pro tato (sebagian mewakili seluruhnya). Ikonisasi pada bagian kepala dan wajah telah mentransformasi kebertubuhan pesawat ke kebertubuhan manusia secara keseluruhan. Ikonisasi bagian ini menggiring bagian-bagian lain ikut menyesuaikan diri, membentuk asosiasi secara utuh dalam benak apresiator. Sebagaimana telah ditunjukkan pada tabel di atas, bagian-bagian lain tersebut bukan menjadi tanda ikonik (mirip) melainkan sebagai indeks.

\section{Relasi Antartokoh dalam Struktur Narasi Film}

Transformasi kebertubuhan pesawat (makhluk tidak hidup) ke kebertubuhan manusia (makhluk hidup) sebagaimana diuraikan di atas lantas mendudukkan tubuh pesawat tersebut sebagai tokoh di dalam cerita. Sebagai tokoh cerita, pesawatpesawat tersebut tentu saling berelasi satu sama lain membangun kesatuan tematik. Cerita itu sendiri hanya bisa dibangun jika terjalin hubungan antartokoh, baik hubungan persamaan, keserasian, perbedaan, hingga konflik. Dan dalam struktur cerita, konflik justru merupakan titik pusat yang meniscayakan sebuah kisah menjadi eksis.

Bagaimana relasi dalam cerita sedemikian diciptakan pengarang (animator, sutradara, seniman)? Pada level ini setiap pengarang memiliki gagasan dasar dan pandangan dunianya masing-masing. Bagaimana pengarang memahami realitas sekaligus akan menunjukkan bagaimana ia harus menciptakan ulang realitas tersebut di dalam karyanya. Sebagai karya film animasi, Planes juga diciptakan dalam kerangka tersebut.

Relasi-relasi dalam struktur film animasi Planes sejauh kisah yang dibangunnya menunjukkan hubungan konvensional-sistemik. Planes, dalam banyak hal, dapat dirujukkan ke dalam strukturalisme Saussure. Di dalam bukunya, Course In Genereal Linguistics, Saussure membagi relasi bahasa ke ke-duaan (dikotomi), yakni penanda versus petanda. Relasi antara keduanya bersifat akustik, bunyi bahasalah yang membedakan makna (Saussure, 1990: 12-13). Dengan kata lain, di dalam hubungan ini makna bahasa tidak ditentukan oleh realitas di luar dirinya, melainkan oleh relasi di dalam struktur itu sendiri. Kata merah (e), misalnya, bermakna merah sebab relasinya dengan kata lain yang muncul di dalam spektrum bunyi, misalnya marah (a) dan murah (u).

Berdasar pada teori itu, tokoh Dusty dengan visualisasi tubuhnya sebagaimana telah dideskripsikan tidak memiliki makna yang bisa dirujuk dari luar cerita. Dusty hanya bermakna dalam relasinya dengan tokoh lain di dalam struktur cerita. Di situ, Dusty bermakna sebagai "Dusty" si penyemprot hama sebab relasinya dengan tokoh lain, terutama dengan Ripslinger sebagai kompetitor atau lawannya. Ripslinger adalah sang juara bertahan reli dunia, bertubuh ramping dan proporsional sebagai pembalap. Kedua tokoh ini berelasi 
secara berlawanan (binary opposition). Berikut detil relasi keberlawanan kedua tokoh tersebut:

Tentu saja Planes tidak hanya berkisah tentang pertentangan kedua tokoh tersebut. Berbagai relasi dengan tokoh lain juga dibangun sepanjang cerita. Akan tetapi, fungsi utama alur kisahnya bertumpu pada Dusty versus Ripslinger. Berbagai peristiwa yang menyangkut relasi dengan tokoh lain atau antara-tokoh lain selain Dusty dan Ripslinger hanya berposisi sebagai fungsi katalisator, yakni sebagai peristiwa penghubung ke fungsi utama. Kemenangan Dusty atas Ripslinger menjadi klimak sekaligus akhir film animasi ini.

Mekanisme pembentukan relasi antartokoh sedemikian sejalan dengan transformasi kebertubuhan sebagaimana telah diuraikan pada bagian sebelumnya. Keduanya merupakan model "struktural" yang sistemik. Dengan kata lain, animator menciptakan sebuah struktur narasi secara otonom, baik narasi verbal maupun visualnya. Sebagai narasi yang otonom, tidak terdapat kaitan langsung antara narasi dalam film dengan realitas di luar dirinya. Pesan dan makna Planes hanya dibangun oleh relasi antarelemen di dalam struktur. Bagaimanapun pesawat yang bisa berbicara tidak pernah ada di dalam realitas.

\section{Dari Transformasi Kebertubuhan ke Arah Pembentukan Mitos}

Transformasi kebertubuhan melalui ikonisasi dan indekalisasi serta pembentukan relasi antarelemen narasi yang mekanistik-sistemik sebagaimana telah diuraikan di atas, pada akhirnya melahirkan sebuah dunia atau realitas baru, yakni realitas karya animasi Planes itu sendiri. Model pembentukan realitas dalam animasi ini berbeda dengan model yang terjadi pada animasi yang menggunakan binatang sebagai tokoh ceritanya. Perbedaan itu tampak mencolok terutama pada fakta bahwa yang satu berbasis pada tokoh yang hidup (makhluk hidup), sedangkan yang lain sebaliknya (makhluk tidak hidup).

Oleh sebab itu, Planes bisa dikatakan sebagai film animasi dengan genre tersendiri. Paling tidak, Planes merepresentasikan sebuah upaya dari animatornya dalam membuka jalan ke arah pembentukan genre animasi secara berbeda. Model ini kiranya bisa mengisnpirasi para kreator lain di bidang animasi untuk terus-menerus menciptakan model-model baru dalam penciptaan. Analoginya, jika pesawat yang notabene sebagai makhluk tidak hidup tersebut bisa ditransformasi menjadi makhluk hidup, niscaya hal yang sama bisa dilakukan pada benda-benda lain:

Tabel 3: Perbandingan model tokoh

\begin{tabular}{|l|l|}
\hline DUSTY & Pendek, terbang rendah, penyemprot hama, ladang \\
\hline RIPSLINGER & $\begin{array}{l}\text { Atletis, ramping, terbang tinggi, pembalap, juara } \\
\text { dunia, kota }\end{array}$ \\
\hline
\end{tabular}


bangunan, alat rumah tangga, pakaian, tiang listrik, telepon seluler, komputer, dan seterusnya.

Sebagaimana telah diuraikan, transformasi di dalam Planes sendiri sebenarnya hanya dilakukan pada elemen tertentu, tetapi pilihan elemen tersebut mampu merepresentasikan atau mewakili keseluruhannya (part pars prototo). Di luar itu, Planes tidak melakukan perubahan. Pada aspek tematik cerita, misalnya, Planes masih tetap mempertahankan model cerita konvensional. Kisah ini merupakan pertarungan antara kerendah-hatian, kejujuran, dan kepejuangan (Dusty) versus kesombongan dan kecurangan (Ripslinger), yang berakhir pada kemenangan yang pertama (Dusty).

Merujuk kepada semiotika Roland Barthes, Planes adalah sebuah model pengucapan (mitos) yang mengukuhkan tipe pengucapan yang telah ada. Dengan kata lain, Planes mengukuhkan mitos, bukan sebaliknya. Pesan semiotik yang hendak dicapai bersifat konvensional, yakni yang jujur akan selalu menang melawan yang sebaliknya. Alibi dari pesan ini biasanya soal pendidikan, yakni kisah dibuat untuk mendidik pembaca (penonton), terutama pembaca dari kalangan generasi penerus. Atau, kisah sedemikian harus diteruskan oleh pembaca kepada generasi penerus, semacam dongeng pengantar tidur. Dalam hal ini, pengarang (animator) mengambil peran sebagai Sang Juru Peta.

Dari situ bisa disimpulkan dua hal. Pertama, Planes adalah sebuah film animasi populer. Ia diciptakan dalam konteks budaya popular, sesuatu yang menghibur dan disukai khalayak. Faktanya memang demikian. Planes diproduksi oleh Disney, sebuah lembaga kenamaan di dunia hiburan. Kedua, basis penciptaan Planes adalah modernisme. Ia memuat kategorisasi yang baik versus yang buruk dimana yang baik harus keluar menjadi pemenang. Dan pesan ini hanya bisa diambil dari relasi antar elemen di dalam teks film. Artinya, tidak ada kaitan antara "yang baik" dan "yang buruk" di film tersebut dengan realitas di luar dirinya. Sebab dalam kenyataan yang terjadi justru sering sebaliknya: si baik malah lebih sering menderita.

Rumusan pesan dan makna yang didapat dari Planes sedemikian tentu tidak bisa dijadikan ukuran untuk menjustifikasi kelebihan atau kelemahan Planes. Alih-alih dijadikan ukuran, hal itu bisa dilihat sebagai celah pengembangan dunia animasi. Sebagaimana telah disampaikan, dari sisi mentransformasi aspek kebertubuhan, Planes-bisa dibandingkan pula dengan film sejenis sebelumnya, yakni Cars-telah membuka celah ke arah pembentukan genre berbeda dari animasi. Jika demikian, lapis tematik makna dan pesan juga bisa dilihat sebagai peluang untuk melengkapi keberbedaan tersebut. Jika Planes berhenti pada bentuk dan tidak mengubah lapis tematik, tantangan bagi penciptaan berikutnya bisa melingkupi aspek ini: melakukan kontramitos secara keseluruhan. Dari perspektif ini, Planes menjadi semacam pemberi rekomendasi atau setidaknya stimulus untuk penciptaan berikutnya.

Lebih jauh, Planes memberi ruang terbuka bagi terciptanya mitos baru, yakni mitos tentang "benda-benda mati yang hidup". Kata kerja 'to animate' dari Wells yang dikutip pada awal tulisan ini tidak berhenti pada arti "memberi hidup/nyawa" dalam batas personifikasi (seolah-olah hidup/bernyawa) melainkan sebuah transformasi yang menjadikannya betulbetul hidup. Sebagai model pengucapan, mitos akan terbentuk dan melekat 
(tersosialisasi) dalam benak khalayak jika frekuensi pengucapannya dilakukan secara intens dan kontinyu. Jika fabel (kisah binatang yang berbicara) merupakan mitos yang dibangun oleh manusia pada ruang dan waktu masa lalu dalam tradisi lisan primer, kisah benda mati berbicara sangat dimungkinkan terbentuk sebagai mitos manusia pada ruang dan waktu masa kini atau masa depan dalam tradisi lisan tertier (digital).

\section{SIMPULAN}

Demikian dalam uraian di atas telah dikemukakan jawaban analitis-kritis terhadap rumusan persoalan yang disampaikan di awal. Telah ditemukan bahwa Planes adalah sebuah film animasi yang tidak hanya menampilkan kisah, baik secara visual maupun verbal, tetapi juga menghadirkan satu bentuk transformasi kebertubuhan, yakni dari benda mati ke tubuh yang hidup. Planes tidak sekedar menunjukkan bagaimana personifikasi dalam wujud visual dan verbal melahirkan kesan hidup (bergerak, berbicara, bernafas, dan lain-lain), tetapi juga menghadirkan hidup itu sendiri. Bukan imajinasi tentang "hidup" yang dijejakkan di benak penonton (di sini, di dalam pikiran) melainkan hidup itu sendiri di dalam layar (di sana, berdiri sendiri di luar pikiran).

Relasi antarelemen cerita, alur, pesan, dan makna Planes tidak menghadirkan sesuatu yang berbeda dengan yang terjadi dalam cerita manusia pada umumnya. Dengan kata lain, di sini Planes mengisahkan sesuatu yang konvensional, hal yang sama sekali sebaliknya dari mekanisme transformasi kebertubuhan yang dilakukannya. Fakta tekstual ini dapat disimpulkan sebagai upaya yang justru memperkuat transformasi kebertubuhan tadi. Dengan cara demikian menjadi semakin tampak upaya pemindahan dunia benda mati (pesawat) itu ke dalam dunia makhluk hidup (manusia). Di dalam Planes sudah tidak ada lagi benda mati itu, yang hadir adalah yang hidup sebagaimana layaknya hidup manusia. Kisah planes (pesawat) adalah kisah manusia. Dengan cara ini, Planes telah membuka ruang bagi terbentuknya mitos baru, yakni mitos tentang "kehidupan benda-benda mati yang (ternyata) hidup". Planes dapat dibandingkan dengan fabel. Jika fabel merupakan mitos yang dikonstruksi manusia masa lalu (zaman kelisanan primer), kisah benda-benda berbicara merupakan mitos masa kini (zaman kelisanan digital).

Fakta demikian ditemukan melalui kajian dalam perspektif semiotika Peirce yang dikombinasikan dengan semiotika struktural Saussure dan Barthes. Hal ini berarti bahwa temuan tersebut bersifat spesifik, terbatas dalam kerangka metode bersangkutan. Oleh sebab itu, sangat dimungkinkan ditemukan fakta yang berbeda jika perspektif yang digunakan untuk mengkajinya berbeda. Hal ini menjadi rekomendasi penulis untuk peneliti selanjutnya. Sebagai sebuah karya yang berada dalam ranah kesenian, Planes memberi ruang tidak terbatas untuk ditafsirkan. Penulis sendiri telah merencanakan riset sejenis dengan objek yang berbeda, dengan harapan dapat memperkaya dan sekaligus memperkuat temuan pada riset ini.

\section{Catatan Akhir}

${ }^{1}$ James Danandjaya, dalam bukunya, Folklor Tionghoa (2007: 79-130) menjelaskan beberapa hewan yang telah menjadi mitos dalam kehidupan manusia, terutama di Tionghoa.

2 Thomas and Friends merupakan film boneka animasi yang menggunakan kereta api sebagai karakternya. Film animasi ini memiliki 
sejarah yang cukup panjang, dimulai dari buku cerita yang ditulis Wilbert Awrdy (1943); kemudian pada 1945 Edmund Ward menulis buku cerita "The Three Railway Engines", dan pada 1946 Awrdy menciptakan boneka mainan dari kayu yang diberi nama Thomas dan kemudian membuat cerita tentangnya. Pada 1984, cerita itu dialihmediakan menjadi film animasi dan ditayangkan di televisi sampai kini.

${ }^{3}$ Seperti Planes, Cars merupakan film animasi yang menggunakan objek benda mati, yakni mobil, sebagai karakter. Cars juga diproduksi oleh Pixar Animation Studios dan dirilis oleh Walt Disney Pictures pada 9 Juni 2006.

${ }^{4}$ Walter J. Ong menggunakan istilah "kelisanan primer" untuk masyarakat masa lalu yang belum mengenal huruf (tulisan). Istilah ini digunakan untuk membedakan dari tradisi lisan lain, yakni tradisi lisan pada masyarakat yang sudah mengenal tulisan. Ong menyebutnya sebagai tradisi lisan sekunder, yakni kelisanan yang dibentuk karena teknologi elektronik, terutama radio dan televisi. Meneruskan Ong, saat ini muncul kelisanan yang dibentuk oleh komputer, yakni tradisi lisan di dunia virtual (media sosial). Penulis menyebut fenomena tersebut sebagai tradisi lisan tertier (tradisi lisan yang dibentuk oleh masyarakat digital). Esai penulis tentang istilah ini dimuat pada Harian Kompas (02/01/2015) berjudul, "Tubuh Digital dan Kelisanan Tertier".

${ }^{5}$ Saussure membedakan langua dari parole. Langua adalah sistem bahasa (yang terdapat dalam kamus), gramatika, sedangkan parole adalah ujaran individu (ekspresi).

${ }^{6}$ Okke KS Zaimar, dalam bukunya, Menelusuri Makna Ziarah Karya Iwan Simatupang (1991) menggunakan istilah ini. Menurut Zaimar, fungsi utama adalah pesan atau gagasan utama cerita yang dimanivestasikan pada narasi (rangkaian peristiwa) dalam alur. Fungsi utama dibedakan dari fungsi katalisator. Fungsi katalisator merupakan narasi yang menjadikan cerita "bercabang" (termasuk flashback), tetapi tetap membangun jalinan pada fungsi utama.

7 Dalam buku Penulisan Sejarah Jawa (1974), C.C. Berg menulis bahwa mitos bersifat mensosialisasi dank arena mekanisme ini, mitos diterima dengan keyakinan, bukan oleh rasionalitas pikiran.

${ }^{8}$ Bagian ini, terutama tentang munculnya tradisi lisan digital, merupakan pengembangan riset yang sedang penulis lakukan.

\section{Daftar Pustaka}

Barthes, Roland

1983 Mythologies (selected and translated from the French by Annette Lavers). London: Granada Publishing.

Hoed, Benny H.

2011 Semiotik dan Dinamika Sosial Budaya . Jakarta: Komunitas Bambu.

Khajavi, Javad

(Decoding the Real:) A Multimodal Social Semiotic Analysis of Reality in Animated Documentary". Animation Studies, Online Journal. Vol.6, Tahun 2011.

Ong, Walter J.

2004 Orality and Literacy, The Technologizing of The Word. London and New York: Routledge

Prakoso, Gatot

2010 Pengetahuan Dasar Film Animasi Indonesia. Jakarta: Yayasan Seni Visual Indonesia.

Saussure, Ferdinan de.

1990 Course in General Linguistics. London: Duckworth

Short, T.L.

2007 Peirce's Theory of Sign. New York: Camridge University Press.

Synnott, Anthony.

2003 Tubuh Sosial, Simbolisme, Diri, dan Masyarakat. Yogyakarta: Jalasutra

Wells, Paul.

2000 Understanding Animation. London and New York: Routledge 